\title{
Determinan Preferensi Konsumen Memilih Hotel Syariah di Kabupaten Jember
}

\author{
Duwi Yunitasari \\ Universitas Jember \\ duwiyunita.feb@unej.ac.id
}

\author{
Ines Cynthia Thresia Riswanda \\ Universitas Jember \\ ines2301@gmail.com
}

\author{
Nanik Istiyani \\ Universitas Jember \\ istiyanife@gmail.com
}

\begin{abstract}
Abstrak Hotel syariah merupakan hotel yang memperhatikan nilai moralitas, adat, dan nilai agama. Hotel syariah memiliki prospek besar untuk dikembangkan karena adanya revolusi halal yang menciptakan kesadaran tinggi bagi konsumen agar lebih memperhatikan tuntutan Agama Islam. Penelitian ini bertujuan untuk mengetahui determinan preferensi konsumen memilih hotel syariah di Kabupaten Jember dan pengaruh variabel pengetahuan tentang hotel syariah, produk, tarif, lokasi, serta aksesibilitas terhadap preferensi konsumen memilih hotel syariah di Kabupaten Jember. Data penelitian ini menggunakan data persepsi responden dan jumlah tamu menginap di hotel syariah maupun konvensional Kabupaten Jember tahun 2019. Penelitian ini dianalisis menggunakan regresi logistik yang diolah dengan SPSS 25. Sebelum melakukan analisis regresi logistik, data ordinal yang diperoleh dari responden akan diubah menjadi data interval menggunakan Method of Successive Interval. Hasil penelitian ini menunjukkan bahwa terdapat tiga variabel yang merupakan determinan preferensi konsumen memilih hotel syariah di Kabupaten Jember yaitu variabel produk, lokasi, dan aksesibilitas. Variabel produk memiliki pengaruh secara positif terhadap preferensi konsumen memilih hotel syariah di Kabupaten Jember sebesar 51,7\%. Variabel lokasi memiliki pengaruh secara positif terhadap preferensi konsumen memilih hotel syariah di Kabupaten Jember sebesar 22,4\%. Variabel aksesibilitas memiliki pengaruh secara positif terhadap preferensi konsumen memilih hotel syariah di Kabupaten Jember sebesar 35,8\%. Sedangkan variabel pengetahuan tentang hotel syariah dan tarif tidak memengaruhi preferensi konsumen memilih hotel syariah di Kabupaten Jember.
\end{abstract}

Kata Kunci Hotel Syariah, Preferensi Konsumen, Pariwisata

\section{PENDAHULUAN}

Jember memiliki 65 objek wisata yang seringkali dilirik para wisatawan domestik maupun mancanegara. Kabupaten Jember semakin dikenal masyarakat dunia sejak 
didirikannya JFC atau Jember Fashion Carnaval oleh Dynand Fariz. JFC adalah agenda tahunan Kota Jember yang menempati posisi ketiga karnaval level dunia. JFC juga ditetapkan sebagai sepuluh acara unggulan pariwisata dalam Calendar of Events Wonderful Indonesia 2019 oleh Kementerian Pariwisata. Adanya objek wisata dan pagelaran budaya ini mampu meningkatkan jumlah wisatawan di Kabupaten Jember setiap tahunnya yang ditunjukkan pada tabel 1.1

Tabel 1.1 Kunjungan Wisatawan Ke Kabupaten Jember 2014-2018

\begin{tabular}{|c|c|c|c|c|c|c|}
\hline \multirow[t]{2}{*}{ No } & \multirow{2}{*}{$\begin{array}{c}\text { Jenis } \\
\text { Wisatawan }\end{array}$} & \multicolumn{5}{|c|}{ Jumlah Kunjungan (Jiwa) } \\
\hline & & 2014 & 2015 & 2016 & 2017 & 2018 \\
\hline 1 & $\begin{array}{l}\text { Wisatawan } \\
\text { Mancanegara }\end{array}$ & 2.672 & 3.017 & 3.136 & 3.178 & 3.058 \\
\hline 2 & $\begin{array}{l}\text { Wisatawan } \\
\text { Nusantara }\end{array}$ & 917.528 & 1.052 .777 & 1.439 .339 & 1.456 .229 & 1.460 .019 \\
\hline & Total & 920.200 & 1.055 .794 & 1.442 .475 & 1.459 .407 & 1.463 .077 \\
\hline
\end{tabular}

Sumber : Badan Pusat Statistik Kabupaten Jember, 2019

Peningkatan jumlah wisatawan di Kabupaten Jember ini menunjukkan adanya peningkatan permintaan pariwisata. Peningkatan permintaan pariwisata di Kabupaten Jember, menarik para pengusaha untuk berlomba-lomba meningkatkan penawaran produk industri pariwisata, salah satunya yaitu industri perhotelan. Pada umumnya, tujuan utama bisnis perhotelan adalah untuk memperoleh keuntungan sebesar-besarnya. Cukup banyak hotel yang seringkali mengabaikan moralitas, adat, dan nilai agama. Hotel syariah menjadi salah satu pilihan untuk menghindari hal tersebut.

Hotel syariah dianggap memiliki prospek besar untuk dikembangkan. Menurut Saleh et al. (Janitra, 2017), terdapat beberapa faktor yang mendukung perkembangan hotel syariah yaitu 1) daya tarik berbelanja yang tinggi oleh wisatawan Timur Tengah; 2) peraturan keamanan yang ketat dan sulitnya persetujuan visa di negara-negara barat yang menggeser para wisatawan Timur Tengah untuk melakukan wisata ke Timur; 3) revolusi halal yang menciptakan kesadaran tinggi di kalangan para wisatawan muslim karena berkaitan dengan tuntutan agama Islam; 4) pertumbuhan perbankan Islam dan multifinance mendorong minat investor untuk melakukan investasi di bidang produk dan jasa halal yang sesuai dengan prinsip syariah, seperti hotel syariah.

Saat ini, pengembangan pariwisata di Jember mulai difokuskan pada wisata edukasi dan religi. Pengembangan pariwisata religi dan banyaknya wisatawan muslim tentunya menjadi potensi yang besar bagi para pengusaha hotel syariah. Hotel syariah juga dianggap cocok dikembangkan di Kabupaten Jember karena mayoritas penduduk Jember menganut agama Islam. Namun potensi yang besar ini rupanya masih belum dikembangkan secara optimal. Hal ini terlihat dari jumlah hotel atau akomodasi syariah di Kabupaten Jember yang jauh lebih sedikit dibanding hotel konvensional. Untuk mendorong peningkatan populasi hotel syariah di Kabupaten Jember, sangat diperlukan perhatian terhadap preferensi konsumen. Dengan memperhatikan preferensi konsumen terhadap hotel syariah, pengusaha dapat menyesuaikan sarana dan prasarana yang diinginkan konsumen sehingga hotel syariah mampu berkembang dan bersaing dengan hotel konvensional.

Terdapat beberapa penelitian yang membahas mengenai variabel pengaruh preferensi konsumen memilih hotel syariah seperti penelitian (Widyarini \& Kartini, 2014). Dari hasil penelitian tersebut dinyatakan bahwa variabel produk, tarif, dan proses tidak 
berpengaruh terhadap keputusan tamu untuk menginap di hotel syariah. Sedangkan iklan, lokasi, pelayanan, dan sarana fisik berpengaruh terhadap keputusan tamu menginap di hotel syariah.

Menurut penelitian (Rahardi \& Wiliasih, 2016), terdapat tujuh variabel signifikan yang mempengaruhi preferensi konsumen yaitu pengetahuan, citra hotel, layanan pelanggan, lokasi, proses, fasilitas, dan religiusitas. Variabel pengetahuan, citra hotel, lokasi, proses, dan fasilitas memiliki pengaruh positif terhadap preferensi konsumen memilih hotel syariah. Variabel layanan pelanggan dan religiusitas berpengaruh negatif terhadap preferensi konsumen dalam memilih hotel syariah. Variabel dengan peluang terbesar adalah variabel lokasi.

Penelitian yang dilakukan (Saleh, 2017) pada skripsinya yang berjudul "Willingness to Pay (WTP) dan Faktor-Faktor yang Memengaruhi Konsumen dalam Memilih Hotel Syariah di Kota Bandung", menyatakan bahwa variabel citra hotel, fasilitas, religiusitas, dummy jenis kelamin, dummy persepsi, dan Willingness to Pay memiliki pengaruh positif yang signifikan terhadap keputusan konsumen memilih hotel syariah.

Menurut (Huda, Zulihar, \& Rini, 2019) faktor yang memengaruhi persepsi responden dalam memilih hotel syariah berdasarkan hasil analisis regresi logistik adalah citra hotel. Semakin tinggi dan baik citra hotel syariah, maka akan semakin banyak orang memilih untuk menginap di hotel syariah.

Penelitian (Kara, Parmitasari, Alwi, \& Risna, 2019) menyatakan bahwa produk, tarif, proses, dan sarana fisik memiliki pengaruh yang positif dan signifikan terhadap keputusan tamu menginap di hotel syariah, sedangkan variabel promosi, lokasi, dan orang/karyawan berpengaruh tidak signifikan terhadap keputusan tamu menginap di hotel syariah.

Penelitian yang dilakukan oleh (Essa, Rahmi, \& Riani, 2019) menyatakan bahwa terdapat empat faktor yang memengaruhi preferensi wisatawan memilih hotel syariah yaitu religiusitas, lokasi, harga, dan produk.

Berdasarkan latar belakang tersebut, peneliti ingin mengetahui (1) determinan preferensi konsumen memilih hotel syariah di Kabupaten Jember dan (2) pengaruh pengetahuan tentang hotel syariah, produk, tarif, lokasi, dan aksesibilitas terhadap preferensi konsumen memilih hotel syariah di Kabupaten Jember.

\section{LANDASAN TEORI}

\section{Teori Permintaan}

Permintaan atas barang dan jasa didasarkan pada kebutuhan seorang konsumen. Permintaan merupakan keinginan akan produk yang didukung oleh kemampuan dan kesediaan konsumen untuk memperoleh suatu barang atau jasa (Sangadji \& Sopiah, 2013). Teori permintaan menjelaskan permintaan para pembeli terhadap suatu barang, yang mana berkaitan erat dengan harga dan barang yang diminta masyarakat. Hukum permintaan menyatakan bahwa jika harga suatu barang naik, maka jumlah barang yang diminta konsumen akan menurun, cateris paribus. Menurut (Sukirno, 2001), terdapat beberapa faktor penting yang memengaruhi permintaan seseorang yaitu:

a. Harga barang itu sendiri;

b. Harga barang lain yang sejenis atau berkaitan erat dengan barang tersebut;

c. Pendapatan rumah tangga dan pendapatan rata-rata masyarakat;

d. Corak distribusi pendapatan masyarakat;

e. Selera masyarakat;

f. Jumlah penduduk; 
g. Ramalan di masa mendatang.

\section{Permintaan Jasa Pariwisata}

Matheieson dan Wall (Payangan, 2013) menjelaskan bahwa permintaan pariwisata merupakan sejumlah orang yang menginginkan suatu perjalanan dengan menggunakan fasilitas dan pelayanan pada tempat-tempat di daerah tujuan pariwisata. Seseorang memiliki keinginan untuk melakukan wisata karena adanya pengaruh dari faktor-faktor yang menjadi daya tarik yang membuat seseorang rela menghabiskan dana yang cukup besar (Puspitasari, Saleh, \& Yunitasari, 2018). Menurut Yoeti (Payangan, 2013), faktor penentu permintaan jasa pariwisata adalah sebagai berikut:

a) General Demand Factors, yang meliputi daya beli, struktur demografi dan trend, sosial dan budaya, sikap dan motivasi perjalanan, serta peluang dan intensitas pemasaran pariwisata;

b) Determining specific demand factors, yang meliputi harga, daya tarik wisata, aksesibilitas, informasi, dan citra daerah.

\section{Teori Lokasi (August Losch)}

Teori lokasi August Losch (Sjafrizal, 2018) mendasarkan analisisnya pada pemilihan lokasi kegiatan ekonomi pada luas pasar terbesar yang dapat dikuasai. Luas pasar ini dimulai dari lokasi perusahaan hingga menuju lokasi konsumen. Semakin besar pasar yang dikuasai maka akan semakin besar pula keuntungan yang didapatkan. Begitu pula sebaliknya, semakin kecil pasar yang dikuasai maka akan semakin kecil pula keuntungan yang didapatkan.

\section{Teori Perilaku Konsumen}

(Khusaini, 2013) menyatakan bahwa terdapat beberapa asumsi mengenai teori perilaku konsumsi yaitu:

a. Barang yang digunakan dalam teori perilaku konsumsi hanyalah barang yang memiliki manfaat semakin besar.

b. Utilitas atau manfaat yang diperoleh ketika mengonsumsi suatu barang.

c. Hukum pertambahan manfaat yang semakin menurun (the law of diminishing marginal utility) yang menyatakan bahwa suatu barang akan memiliki nilai kepuasan yang semakin kecil jika jumlah konsumsinya semakin banyak.

d. Kemampuan konsumen untuk menentukan prioritas suatu barang yang diinginkan.

e. Konsumen memiliki pengetahuan untuk menentukan keputusan konsumsinya.

Pada kenyataannya, manusia akan dihadapkan pada beberapa pilihan untuk memenuhi kebutuhannya. Pilihan-pilihan ini terpaksa dilakukan karena kebutuhan manusia tidak terbatas, sedangkan alat untuk memenuhi kebutuhan tersebut sangat terbatas (Sangadji \& Sopiah, 2013). Terdapat empat macam perspektif dari model manusia dalam mengambil keputusan menurut (Dwiastuti, Shinta, \& Isaskar, 2012), yaitu:

a. Manusia ekonomi yang melakukan keputusan secara rasional dengan cara mengambil keputusan berdasarkan harga, jumlah barang, utilitas marginal, dan kepuasan.

b. Manusia pasif yang mementingkan diri sendiri dan menerima segala promosi yang ditawarkan di pasar.

c. Manusia kognitif yang mencari dan mengevaluasi terlebih dahulu mengenai merk produk atau jasa. 
d. Manusia emosional yang menggunakan emosinya untuk memilih suatu produk atau jasa.

\section{Hotel Syariah}

Menurut (Janitra, 2017), hotel syariah merupakan hotel atau akomodasi penyedia jasa pelayanan, penginapan, makanan dan minuman, serta jasa lain bagi umum yang dikelola secara komersial dan memenuhi ketentuan pemerintah, industri, dan syariah. Hotel syariah harus sesuai dengan ketentuan yang telah ditetapkan oleh Dewan Syariah Nasional. Rezeki (Fadhli, 2018) menyimpulkan bahwa standar atau kriteria hotel syariah sebagai berikut:

a. Segala fasilitas yang dimiliki hotel syariah harus memiliki manfaat bagi tamu dan tidak mengakibatkan kerusakan, kemungkaran, maupun eksploitasi wanita;

b. Dilakukan seleksi pada tamu yang akan check-in;

c. Terbuka bagi siapa saja yang tidak merupakan penganjur kerusakan, kemungkaran, permusuhan, dan sejenisnya;

d. Makanan dan minuman yang disediakan harus terjamin kehalalannya;

e. Dekorasi yang digunakan harus sesuai dengan keindahan dalam Islam dan tidak bertentangan dengan syariah;

f. Operasional yang mencangkup kebijakan, pengelola SDM, dan keuangan harus sesuai dengan syariat Islam;

g. Jalannya operasional hotel diawasi oleh Dewan Pengawas Syariah;

h. Pelayanan hotel syariah harus sesuai dengan kaidah dan batasan Islam.

\section{METODOLOGI PENELITIAN}

\section{Jenis Penelitian}

Penelitian ini merupakan penelitian kuantitatif eksplanatori yang bertujuan untuk mengetahui determinan preferensi konsumen memilih hotel syariah dan pengaruh masing-masing variabel terhadap preferensi konsumen memilih hotel syariah di Kabupaten Jember.

\section{Populasi dan Sampel}

Populasi yang digunakan dalam penelitian ini adalah tamu yang menginap di hotel syariah maupun konvensional di Kabupaten Jember pada tahun 2019 yaitu sebesar 513.571 orang yang terdiri dari 506.016 pengunjung hotel konvensional dan 7.555 pengunjung hotel syariah. Sampel diperoleh menggunakan rumus Slovin sebagai berikut:

Keterangan:

$$
n=\frac{N}{1+d^{2}}
$$

$\mathrm{n} \quad=$ jumlah sampel minimal yang diperlukan

$\mathrm{N} \quad=$ Jumlah populasi

$\mathrm{d} \quad=$ alpha 0,1

Berdasarkan rumus tersebut, $n=\frac{513571}{1+0,1^{2}}=98,826$. Sehingga sampel minimum dalam penelitian ini adalah sebesar 99 responden.

\section{Jenis dan Sumber Data}

Jenis data yang digunakan dalam penelitian ini adalah data primer dan data sekunder. Data primer diperoleh melalui hasil wawancara dan pengisian kuesioner yang dibagikan secara langsung maupun tidak langsung (online) kepada responden. Data sekunder 
diperoleh dari Badan Pusat Statistik, Dinas Pariwisata dan Kebudayaan Kabupaten Jember, buku, jurnal, skripsi, website, dan referensi lain yang berkaitan dengan penelitian yang akan dilakukan.

\section{Metode Analisis Data}

Penelitian ini dianalisis menggunakan analisis regresi logistik (LOGIT). Data diolah menggunakan Microsoft Excel 2013 dan SPSS 25. Sebelum melakukan analisis regresi logistik, data akan diubah menjadi data interval menggunakan Method of Successive Interval dan dilakukan beberapa uji yang meliputi uji validitas dan uji realibilitas. Menurut (Ghozali, 2016), model regresi logistik variabel k menggunakan persamaan sebagai berikut:

$$
\operatorname{Ln}\left[\operatorname{odds}\left(S \mid X_{1}, X_{2}, \ldots, X_{3}\right)\right]=\beta_{0}+\beta_{1} X_{1}+\beta_{2} X_{2}+\ldots \ldots+\beta_{k} X_{k}
$$

Dimana $\beta_{0}=$ koefisien konstanta,

$\beta_{1}=$ koefien variabel X1

$\beta_{\mathrm{k}}=$ koefisien variabel $\mathrm{Xk}$

\section{HASIL PENELITIAN}

\section{Uji Validitas}

Dalam penelitian ini, diketahui jumlah $\mathrm{N}$ sebesar 110 responden dengan tingkat kepercayaan sebesar 95\% $(\alpha=5 \%)$ sehingga diperoleh jumlah $r_{\text {tabel }}=0,1874$. Uji validitas setiap variabel akan dijelaskan sebagai berikut:

a. Pengetahuan Tentang Hotel Syariah (X1)

Tabel 4.1 Hasil Uji Validitas Variabel X1

\begin{tabular}{|c|c|c|c|}
\hline Butir Pertanyaan & $\mathrm{r}_{\text {hitung }}$ & $\mathrm{r}_{\text {tabel }}$ & Keterangan \\
\hline $\mathrm{X} 1.1$ & 0,747 & 0.1874 & Valid \\
\hline $\mathrm{X} 1.2$ & 0,769 & 0.1874 & Valid \\
\hline $\mathrm{X} 1.3$ & 0,675 & 0.1874 & Valid \\
\hline $\mathrm{X} 1.4$ & 0,714 & 0.1874 & Valid \\
\hline $\mathrm{X} 1.5$ & 0,692 & 0.1874 & Valid \\
\hline
\end{tabular}

Pertanyaan yang berkaitan dengan variabel pengetahuan tentang hotel syariah (X1) terdiri dari 5 butir pertanyaan. Berdasarkan hasil uji validitas yang disajikan pada tabel 4.1 dapat disimpulkan bahwa 5 butir pertanyaan dalam kuesioner dinyatakan valid karena rhitung $>r_{\text {tabel. }}$

b. Produk (X2)

Tabel 4.2 Hasil Uji Validitas Variabel X2

\begin{tabular}{|c|c|c|c|}
\hline Butir Pertanyaan & $\mathrm{r}_{\text {hitung }}$ & rtabel & Keterangan \\
\hline X2.1 & 0,581 & 0.1874 & Valid \\
\hline X2.2 & 0,770 & 0.1874 & Valid \\
\hline X2.3 & 0,785 & 0.1874 & Valid \\
\hline X2.4 & 0,666 & 0.1874 & Valid \\
\hline X2.5 & 0,694 & 0.1874 & Valid \\
\hline
\end{tabular}

Pertanyaan yang berkaitan dengan variabel produk (X2) terdiri dari 5 butir soal. Berdasarkan hasil uji validitas yang disajikan pada tabel 4.2 dapat disimpulkan bahwa 5 butir pertanyaan dalam kuesioner dinyatakan valid karena $r_{\text {hitung }}>r_{\text {tabel }}$

c. Tarif (X3)

Tabel 4.3 Hasil Uji Validitas X3 


\begin{tabular}{|c|c|c|c|}
\hline Butir Pertanyaan & $\mathrm{r}_{\text {hitung }}$ & $\mathrm{r}_{\text {tabel }}$ & Keterangan \\
\hline X3.1 & 0,765 & 0.1874 & Valid \\
\hline X3.2 & 0,698 & 0.1874 & Valid \\
\hline X3.3 & 0,826 & 0.1874 & Valid \\
\hline X3.4 & 0,767 & 0.1874 & Valid \\
\hline X3.5 & 0,756 & 0.1874 & Valid \\
\hline
\end{tabular}

Pertanyaan yang berkaitan dengan variabel tarif (X4) terdiri dari 5 butir pertanyaan. Berdasarkan hasil uji validitas variabel tarif yang disajikan pada tabel 4.3, 5 butir pertanyaan tersebut dinyatakan valid karena $r_{h i t u n g}>r_{\text {tabel. }}$

d. Lokasi (X4)

Tabel 4.4 Uji Validitas Variabel X4

\begin{tabular}{|c|c|c|c|}
\hline Butir Pertanyaan & $\mathrm{r}_{\text {hitung }}$ & $\mathrm{r}_{\text {tabel }}$ & Keterangan \\
\hline $\mathrm{X} 4.1$ & 0,774 & 0.1874 & Valid \\
\hline $\mathrm{X} 4.2$ & 0,694 & 0.1874 & Valid \\
\hline $\mathrm{X} 4.3$ & 0,730 & 0.1874 & Valid \\
\hline $\mathrm{X} 4.4$ & 0,736 & 0.1874 & Valid \\
\hline $\mathrm{X} 4.5$ & 0,828 & 0.1874 & Valid \\
\hline
\end{tabular}

Pertanyaan yang berkaitan dengan variabel lokasi (X4) terdiri dari 5 butir pertanyaan. Berdasarkan hasil uji validitas variabel lokasi yang disajikan pada tabel 4.4, 5 butir pertanyaan tersebut dinyatakan valid karena $r_{h i t u n g}>r_{\text {tabel. }}$

e. Aksesibilitas (X5)

Tabel 4.5 Hasil Uji Validitas Variabel X5

\begin{tabular}{|c|c|c|c|}
\hline Butir Pertanyaan & $\mathrm{r}_{\text {hitung }}$ & $\mathrm{r}_{\text {tabel }}$ & Keterangan \\
\hline X5.1 & 0,768 & 0.1874 & Valid \\
\hline X5.2 & 0,687 & 0.1874 & Valid \\
\hline X5.3 & 0,708 & 0.1874 & Valid \\
\hline X5.4 & 0,775 & 0.1874 & Valid \\
\hline X5.5 & 0,699 & 0.1874 & Valid \\
\hline
\end{tabular}

Pada kuesioner yang diberikan kepada responden, terdapat 5 butir pertanyaan yang berkaitan dengan variabel aksesibilitas. Berdasarkan hasil uji validitas yang disajikan pada tabel $4.5,5$ butir pertanyaan tersebut dinyatakan valid karena $r_{\text {hitung }}>r_{\text {tabel. }}$.

\section{Uji Realibilitas}

4.6 Hasil Uji Realibilitas Variabel Penelitian

\begin{tabular}{|c|c|c|c|}
\hline Variabel Penelitian & Cronbach Alpha & $\begin{array}{c}\text { Cut of } \\
\text { Value }\end{array}$ & Keterangan \\
\hline $\begin{array}{c}\text { Pengetahuan tentang } \\
\text { hotel syariah }\end{array}$ & 0,767 & 0,70 & Realibel \\
\hline Produk & 0,737 & 0,70 & Realibel \\
\hline Tarif & 0,821 & 0,70 & Reliabel \\
\hline Lokasi & 0,807 & 0,70 & Realibel \\
\hline Aksesibilitas & 0,777 & 0,70 & Realibel \\
\hline
\end{tabular}

Berdasarkan tabel 4.6, ditunjukkan bahwa seluruh variabel penelitian ini memiliki nilai Cronbach Alpha lebih besar dari 0,70. Dengan demikian dapat disimpulkan bahwa 5 variabel yang digunakan dalam penelitian ini bersifat reliabel. 


\section{Analisis Regresi Logistik}

Analisis logistik dilakukan untuk mengetahui beberapa variabel yang diduga merupakan preferensi konsumen memilih hotel syariah di Kabupaten Jember. Variabel independen dalam penelitian ini meliputi pengetahuan tentang hotel syariah, produk, tarif, lokasi, dan aksesibilitas. Sedangkan variabel dependen dalam penelitian ini akan dilihat dari dua kemungkinan yaitu responden yang lebih memilih untuk menginap di hotel syariah $(\mathrm{Y}=1)$ dan responden yang tidak memilih untuk menginap di hotel syariah atau lebih memilih hotel konvensional $(\mathrm{Y}=0)$. Pengujian ini menggunakan tingkat kepercayaan sebesar $95 \%(\alpha=5 \%)$. Tahap pertama yang dilakukan dalam analisis logistik adalah menilai Overall Model Fit. Overall Model Fit dapat dilihat dari nilai -2LogL yang disajikan pada tabel 4.7

\begin{tabular}{|c|c|c|}
\hline No & $-2 \log L$ & Nilai \\
\hline 1 & Awal & 152,456 \\
\hline 2 & Akhir & 100,866 \\
\hline
\end{tabular}

Sumber : Hasil olahan SPSS 25, 2020

Berdasarkan tabel 4.7, nilai -2LogL tanpa variabel atau hanya konstanta saja sebesar 152,456 . Sedangkan setelah dimasukkan lima variabel baru, terjadi penurunan nilai 2LogL menjadi 100,866. Selisih nilai kedua -2LogL sebesar 51,59 dengan df 5 (109-104) dan angka ini signifikan secara statistik karena nilainya lebih besar dari tabel $(51,59>11,0705)$ sehingga variabel independen dalam penelitian ini memperbaiki model fit.

\begin{tabular}{ccccc}
\multicolumn{4}{c}{ Tabel 4.8 Hasil Uji Pengaruh Simultan (Omnibus Test) } \\
\hline & & Chi-square & Df & Sig. \\
\hline Step 1 & Step & 51,590 & 5 &, 000 \\
& Block & 51,590 & 5 &, 000 \\
& Model & 51,590 & 5 &, 000 \\
\hline
\end{tabular}

Sumber : Hasil olahan SPSS 25, 2020

Berdasarkan tabel 4.8, ditunjukkan bahwa penelitian ini memiliki signifikansi nilai omnibus sebesar 0,000 yang mana lebih kecil dari taraf nyata yang digunakan yaitu 0,05 . Dari hasil tersebut dapat disimpulkan bahwa setidaknya terdapat 1 variabel independen yang berpengaruh nyata terhadap variabel dependen.

Tabel 4.9 Hasil Uji Koefisien Determinasi

\begin{tabular}{cccc}
\hline Step & $\begin{array}{c}-2 \text { Log } \\
\text { likelihood }\end{array}$ & $\begin{array}{c}\text { Cox \& Snell R } \\
\text { Square }\end{array}$ & $\begin{array}{c}\text { Nagelkerke R } \\
\text { Square }\end{array}$ \\
\hline 1 & $100,866^{\mathrm{a}}$ &, 374 &, 499 \\
\hline Sumber : Hasil olahan SPSS 25,2020 &
\end{tabular}

Pada tabel 4.9, ditunjukkan bahwa Cox \& Snell R Square memiliki nilai sebesar 0,374 dan Nagelkerke R Square memiliki nilai sebesai 0,499 yang berarti bahwa variabel independen dapat menjelaskan variabel dependen sebesar 49,9\%, sedangkan $50,1 \%$ sisanya dijelaskan oleh variabel lain di luar model.

Tabel 4.10 Hasil Uji Kecocokan Model (Hosmer Lemeshow Test)

\begin{tabular}{cccc}
\hline Step & Chi-square & Df & Sig. \\
\hline 1 & 4,987 & 8 &, 759 \\
\hline
\end{tabular}

Sumber : Hasil olahan SPSS 25, 2020 
Berdasarkan tabel 4.10, dapat dilihat bahwa hosmer lemeshow test memiliki nilai sebesar 4,987 dengan probabilitas signifikansi sebesar 0,759 yang nilainya jauh di atas taraf nyata 0,05 . Dengan demikian dapat disimpulkan bahwa model dalam penelitian ini sesuai dan layak untuk dianalisis.

Tabel 4.11 Hasil Uji Tabel Klasifikasi

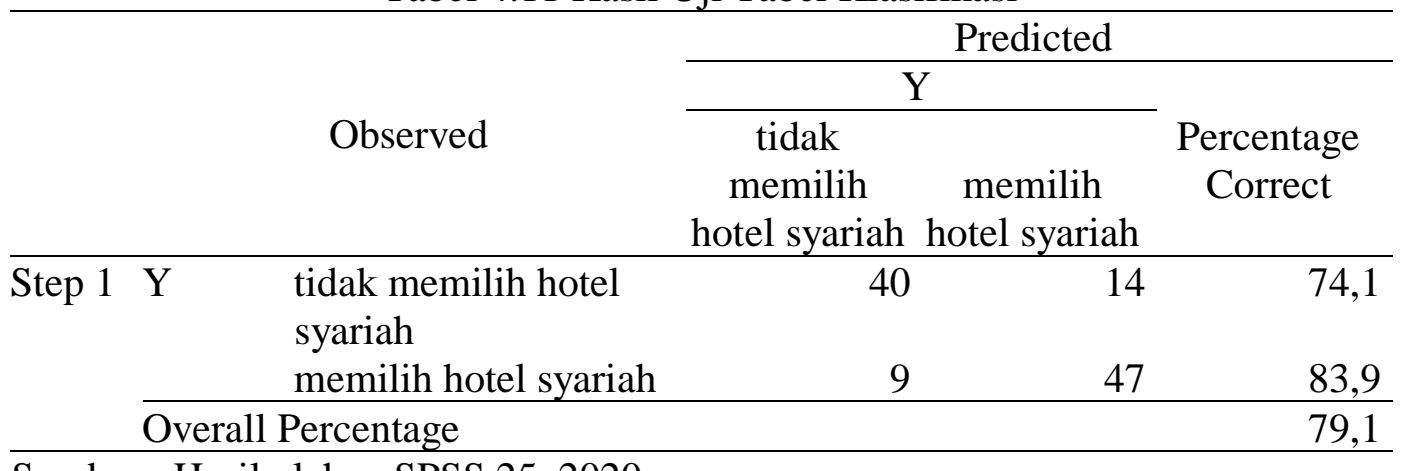

Sumber : Hasil olahan SPSS 25, 2020

Berdasarkan tabel 4.11, ditunjukkan bahwa pada kolom prediksi konsumen yang tidak memilih hotel syariah sebesar 54 responden, namun pada hasil observasi hanya sebesar 40 responden sehingga dapat disimpulkan bahwa ketepatan klasifikasinya sebesar $74,1 \%$ (40/54). Sedangkan pada kolom prediksi konsumen yang memilih hotel syariah jumlahnya sebesar 56 responden, namun pada hasil observasinya hanya sebesar 47 responden sehingga dapat disimpulkan bahwa ketepatan klasifikasinya sebesar 83,6\% (47/56). Dengan demikian, ketepatan klasifikasi secara keseluruhan model sebesar $79,1 \%$.

Tabel 4.12 Hasil Uji Koefisien Regresi

\begin{tabular}{clcccccc}
\hline & & B & S.E. & Wald & Df & Sig. & Exp(B) \\
\hline Step & X1_pengetahuan &,- 023 &, 082 &, 079 & 1 &, 779 &, 977 \\
$1^{\mathrm{a}}$ & X2_produk &, 517 &, 121 & 18,187 & 1 &, 000 & 1,676 \\
& X3_tarif &, 031 &, 081 &, 148 & 1 &, 700 & 1,032 \\
& X4_lokasi &, 224 &, 091 & 6,083 & 1 &, 014 & 1,251 \\
& X5_aksesibilitas &, 358 &, 104 & 11,941 & 1 &, 001 & 1,430 \\
& Constant & $-18,351$ & 4,190 & 19,183 & 1 &, 000 &, 000 \\
\hline
\end{tabular}

Sumber : Hasil olahan SPSS 25, 2020

Berdasarkan tabel 4.12, dapat dilihat bahwa terdapat beberapa variabel independen yang menjadi preferensi konsumen memilih hotel syariah yaitu produk, lokasi, dan aksesibilitas. Taraf nyata dalam penelitian ini adalah sebesar 0,05. Variabel produk memiliki nilai signifikansi sebesar $0,001<0,05$. Variabel lokasi memiliki nilai signifikansi sebesar $0,009<0,05$. Variabel aksesibilitas memiliki nilai signifikansi sebesar $0,001<0,05$. Dengan hasil tersebut, persamaan regresi yang dibentuk adalah sebagai berikut:

$$
\begin{gathered}
\text { Ln } \frac{p}{1-p}=-18,351+\left(-0,023 X_{1}\right)+0,517 X_{2}+0,031 X_{3}+0,224 X_{4}+0,358 X_{5} \\
\text { Atau jika dijabarkan menjadi: } \\
\begin{array}{c}
\operatorname{Ln} \frac{p}{1-p}=-18,351+(-0,023 \text { Pengetahuan })+0,517 \text { Produk }+0,031 \text { Tarif }+0,224 \text { Lokasi }+0,358 \text { Aksesibilitas }
\end{array}
\end{gathered}
$$




\section{Pembahasan}

Model $\operatorname{Ln} \frac{p}{1-p}=-18,351+\left(-0,023 X_{1}\right)+0,517 X_{2}+0,031 X_{3}+0,224 X_{4}+0,358 X_{5}$ dapat diintepretasikan sebagai berikut:

1. Variabel pengetahuan tentang hotel syariah $\left(X_{1}\right)$ memiliki nilai signifikansi sebesar 0,779 . Variabel ini tidak memengaruhi preferensi konsumen memilih hotel syariah di Kabupaten Jember pada taraf nyata 0,05. Terdapat dua hal yang menyebabkan pengetahuan tidak memengaruhi preferensi konsumen dalam memilih hotel syariah di Kabupaten Jember yaitu responden didominasi oleh pelajar/mahasiswa yang rata-rata menginap seorang diri sehingga kurang memedulikan peraturan yang diterapkan di hotel syariah dan adanya rasionalitas terbatas yang dimiliki responden. Penelitian ini sesuai dengan penelitian (Huda, Zulihar, \& Rini, 2019) yang menyatakan bahwa pengetahuan tidak memiliki pengaruh terhadap keputusan konsumen memilih hotel syariah.

2. Variabel produk $\left(\mathrm{X}_{2}\right)$ memiliki nilai signifikansi sebesar 0,000 . Variabel ini secara signifikan memengaruhi preferensi konsumen untuk memilih hotel syariah di Kabupaten Jember pada taraf nyata 0,05 . Nilai koefisien regresi variabel produk sebesar 0,517 dan bernilai positif. Hal ini dapat diartikan bahwa variabel produk berpengaruh secara positif terhadap preferensi konsumen memilih hotel syariah di Kabupaten Jember sebesar 51,7\%. Variabel produk memiliki nilai persentase tertinggi sehingga dapat disimpulkan bahwa variabel produk merupakan faktor utama yang memengaruhi preferensi konsumen memilih hotel syariah di Kabupaten Jember. Menurut Kotler dan Amstrong (Oktavenia \& Ardani, 2019), kualitas produk merupakan senjata strategis yang potensial untuk mengalahkan pesaing. Pernyataan tersebut didukung oleh (Essa, Rahmi, \& Riani, 2019) yang menyatakan bahwa variabel produk menentukan preferensi konsumen memilih hotel syariah, penelitian (Kara, Parmitasari, Alwi, \& Risna, 2019) yang menyatakan bahwa produk berpengaruh secara positif dan signifikan terhadap keputusan tamu menginap pada Hotel Al Badar Syariah Makassar, serta penelitian (Pratiwi \& Latif, 2020) yang berpendapat bahwa produk hotel syariah memengaruhi minat menginap kembali di hotel syariah.

3. Variabel tarif $\left(\mathrm{X}_{3}\right)$ memiliki nilai signifikansi sebesar 0,700. Variabel ini tidak memengaruhi preferensi konsumen memilih hotel syariah di Kabupaten Jember pada taraf nyata 0,05 . Hal ini disebabkan oleh dua hal yaitu: (1) Seluruh hotel syariah di Kabupaten Jember merupakan hotel non bintang yang mana memiliki tarif atau harga yang relatif sama; (2) responden lebih melihat pada lokasi yang lebih dekat dengan tempat tujuan; dan (3) responden tidak mempermasalahkan tarif yang ditawarkan oleh hotel syariah karena merasa lebih aman jika menginap di hotel syariah. Penelitian ini sesuai dengan (Widyarini \& Kartini, 2014) yang menjelaskan bahwa tamu hotel dalam menggunakan layanan Namira Hotel Syariah tidak dipengaruhi oleh tarif. (Huda, Zulihar, \& Rini, 2019) yang menyatakan bahwa tarif atau harga tidak memiliki pengaruh terhadap keputusan konsumen memilih hotel syariah.

4. Variabel lokasi $\left(\mathrm{X}_{4}\right)$ memiliki nilai signifikansi sebesar 0,014. Variabel ini secara signifikan memengaruhi preferensi konsumen memilih hotel syariah di Kabupaten Jember pada taraf nyata 0,05 . Koefisien pada variabel lokasi sebesar 0,224 dan bernilai positif sehingga dapat diartikan bahwa variabel lokasi berpengaruh secara positif terhadap preferensi konsumen memilih hotel syariah di Kabupaten Jember sebesar 22,4\%. Hasil ini sesuai dengan penelitian (Essa, Rahmi, \& Riani, 2019) yang menyatakan bahwa lokasi menjadi salah satu faktor penentu preferensi konsumen 
memilih hotel syariah. Penelitian ini juga sejalan dengan penelitian (Pratiwi \& Latif, 2020), serta (Widyarini \& Kartini, 2014) juga menyatakan bahwa variabel lokasi merupakan salah satu faktor yang berpengaruh terhadap keputusan konsumen memilih hotel syariah.

5. Variabel aksesibilitas (X5) memiliki nilai signifikansi sebesar 0,001. Variabel ini secara signifikan memengaruhi preferensi konsumen memilih hotel syariah di Kabupaten Jember pada taraf nyata sebesar 0,05. Koefisien variabel aksesibilitas sebesar 0,358 dan bernilai positif sehingga dapat diartikan bahwa variabel aksesibilitas berpengaruh secara positif terhadap preferensi konsumen memilih hotel syariah di Kabupaten Jember sebesar 35,8\%. Penelitian ini sesuai dengan (Payangan, 2013), yang menyatakan bahwa aksesibilitas sangat memengaruhi permintaan jasa pariwisata.

\section{KESIMPULAN DAN SARAN}

\section{Kesimpulan}

Berdasarkan lima variabel yang dianalisis, terdapat tiga variabel yang merupakan determinan preferensi konsumen memilih hotel syariah di Kabupaten Jember yaitu produk, lokasi, dan aksesibilitas. Variabel produk, lokasi, dan aksesibilitas berpengaruh secara positif terhadap preferensi konsumen memilih hotel syariah di Kabupaten Jember. Sedangkan variabel pengetahuan tentang hotel syariah dan tarif tidak memengaruhi preferensi konsumen memilih hotel syariah di Kabupaten Jember.

\section{Saran}

Berdasarkan penelitian di atas, saran yang dapat diberikan oleh penulis adalah sebagai berikut:

1. Perlunya promosi dan peningkatan kualitas hotel syariah agar mampu bersaing dengan hotel konvensional.

2. Mengingat adanya keterbatasan pada penelitian ini karena sulitnya menjangkau responden, diharapkan untuk peneliti selanjutnya dapat menjangkau responden lebih luas dan menambah variabel lain untuk memperkuat penelitiannya sehingga dapat memberikan hasil yang lebih maksimal.

3. Diharapkan pemerintah dapat memberikan dorongan terhadap perkembangan bisnis hotel syariah di Indonesia, khususnya di Kabupaten Jember.

\section{DAFTAR PUSTAKA}

Dwiastuti, R., Shinta, A., \& Isaskar, R. (2012). Ilmu Perilaku Konsumen. Malang: UB Press. Retrieved from http://shinta.lecture.ub.ac.id/files/2012/10/PERILAKUKONSUMEN.pdf

Essa, S. P., Rahmi, D., \& Riani, W. (2019). Faktor-Faktor yang Menentukan Preferensi Wisatawan dalam Memilih Hotel Syariah di Bandung. Prosiding Ilmu Ekonomi, 5(1), 24-30. doi:http://dx.doi.org/10.29313/.v0i0.15032

Fadhli, A. (2018). Manajemen Hotel Syariah. Yogyakarta: Gava Media.

Ghozali, I. (2016). Aplikasi Analisis Multivariate dengan Program IBM SPSS 23 (8 ed.). Semarang: Badan Penerbit Universitas Diponegoro.

Huda, N., Zulihar, \& Rini, N. (2019). Faktor yang Mempengaruhi Preferensi Masyarakat Memilih Hotel Syariah. Ekuitas: Jurnal Ekonomi dan Keuangan, 2(4), 490-511. doi:10.24034/j25485024.y2018.v2.i4.4033

Janitra, M. R. (2017). Hotel Syariah Konsep dan Penerapan. Depok: PT. RajaGrafindo. 
Kara, M., Parmitasari, R. D., Alwi, Z., \& Risna. (2019). Bauran Pemasaran Jasa dan Tingkat Hunian Pada Hotel Al-Badar Syariah. Laa Maisyir: Jurnal Ekonomi Islam, 6(1), 53-72. doi:https://doi.org/10.24252/lamaisyir.v6i1.9412

Khusaini, M. (2013). Ekonomi Mikro Dasar-Dasar Teori. Malang: UB Press.

Oktavenia, K. A., \& Ardani, I. G. (2019). Pengaruh Kualitas Produk Terhadap Keputusan Pembelian Handphone Nokia Dengan Citra Merek Sebagai Pemediasi. E-Jurnal Manajemen, 8(3), doi:https://doi.org/10.24843/EJMUNUD.2019.v8.i3.p8

Payangan, O. R. (2013). Pemasaran Jasa Pariwisata. Bogor: IPB Press.

Pratiwi, R., \& Latif, M. I. (2020). Sharia Marketing Mix Terhadap Minat Menginap Kembali di Hotel Grasia Semarang. Magisma, VIII(1), 27-33. doi:https://doi.org/10.35829/magisma.v1i1.66

Puspitasari, I., Saleh, M., \& Yunitasari, D. (2018). Analisis Kontribusi Sektor Pariwisata Terhadap Pendapatan Asli Daerah Kota Batu Periode Tahun 2011-2015. EJournal Ekonomi Bisnis dan Akuntansi, V(1), 11-15. doi:https://doi.org/10.19184/ejeba.v5i1.7720

Rahardi, N., \& Wiliasih, R. (2016). 2016. Jurnal Syarikah, 2(1), 180-192. doi:http://dx.doi.org/10.30997/jsei.v2i1.293

Saleh, S. S. (2017). Willingness To Pay (WTP) dan Faktor-Faktor Yang Memengaruhi Konsumen Dalam Memilih Hotel Syariah di Kota Bandung. Bogor: Institut Pertanian Bogor.

Sangadji, E. M., \& Sopiah. (2013). Perilaku Konsumen: Pendekatan Praktis Disertai Himpunan Jurnal Penelitian. Yogyakarta: Andi.

Sjafrizal. (2018). Analisis Ekonomi Regional dan Penerapannya di Indonesia. Depot: P.T. RajaGrafindo.

Sukirno, S. (2001). Pengantar Teori Mikro Ekonomi. Depok: PT. RajaGrafindo Persada. Widyarini, \& Kartini, F. (2014). Variabel Yang Mempengaruhi Keputusan Pemilihan Hotel Syariah. EKBISI, IX(1), 83-94. 